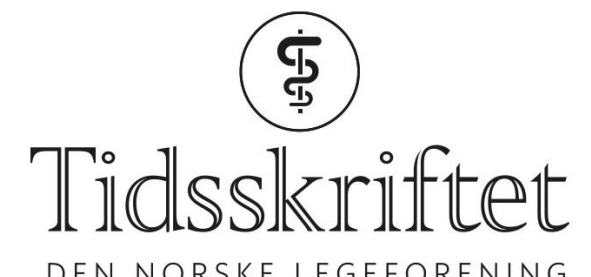

DEN NORSKE LEGEFORENING

\title{
Å ta humor på alvor
}

TIDLIGERE I TIDSSKRIFTET

JULIE DIDRIKSEN

Tidsskriftet

I Tidsskriftets 10o-årsjubileumsnummer, nr. 1A/1981, skrev Ole Didrik Lærum en artikkel om humor i vitenskapen. Under følger et utdrag, blant annet med ufrivillig humoristiske eksempler fra pasientjournaler (Tidsskr Nor Lægeforen 1981; 101: 58-60).

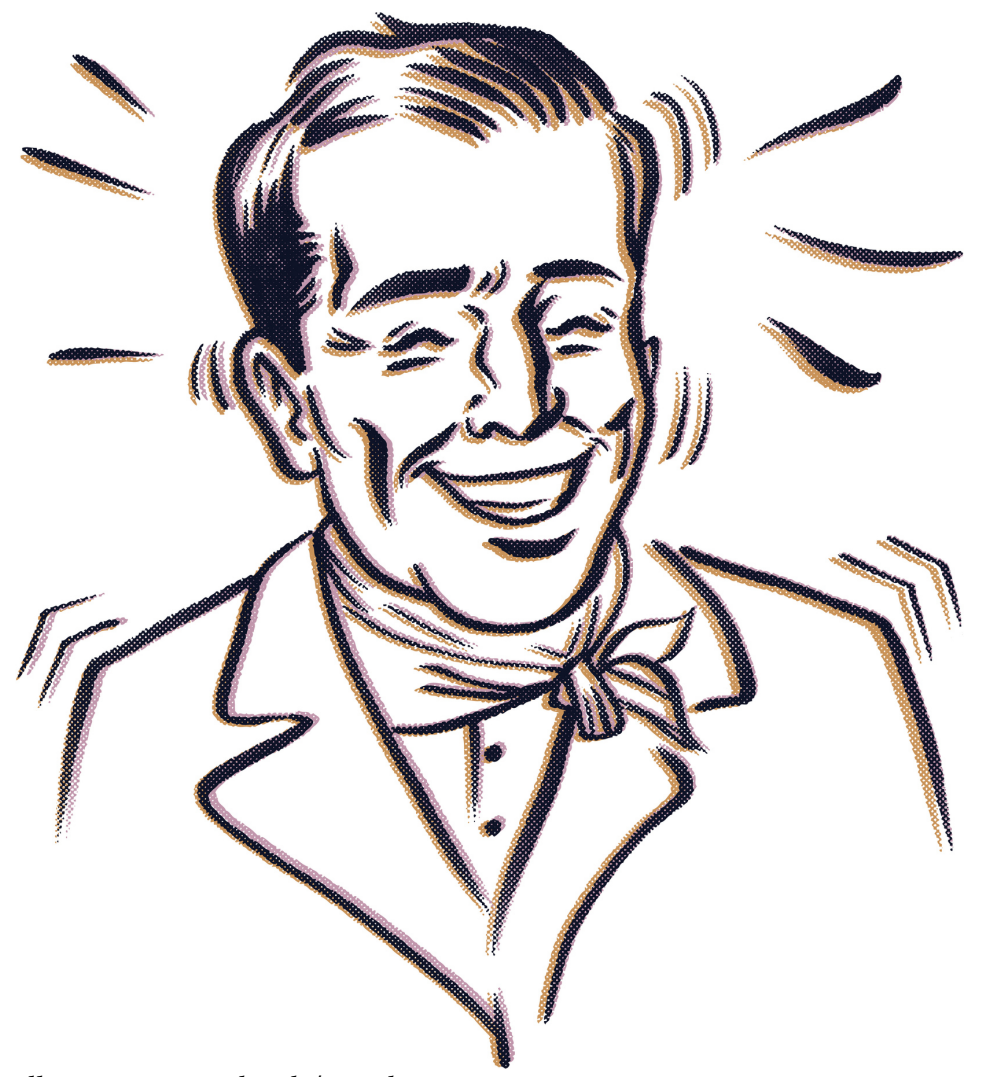

Illustrasjon: amdandy/iStock

\section{Humor i vitenskap og medisin}

Å snakke om medisinsk og vitenskapelig humor er ingen spøk. Det er tvert imot alvor. Humor er vanskelig å definere, men én brukbar definisjon er «alt som får et menneske til å le - unntatt kiling». I tillegg kommer at hva som betraktes som humor er sterkt subjektivt preget. Humor er for eksempel ikke det samme for den som ler og den som blir ledd av. Videre viser humoren geografiske variasjoner.

Jeg har opplevd dette på kroppen. Etter å ha bodd et halvt år i Tyskland, kom jeg en gang i 
skade for å fortelle en vits under en kaffepause på instituttet. Det ble etterfulgt av en isnende taushet. Jeg forsøkte så godt jeg kunne å forklare poenget. Da utbrøt en av kollegene: «Ach so, Sie sind witzig, HA, HA, HA, (jasså, De er vittig, HA, HA, HA).» I løpet av det etterfølgende år hendte det et par ganger til at jeg fortalte en liten historie, men passet da alltid på å si fra på forhånd at det er en vits. Resultatet uteble ikke. Det kom en sterk, langvarig latter mens de stirret meg intenst inn i øynene. Seinere oppdaget jeg at tyskerne hadde en helt annen form for humor enn vi. Trass i alle geografiske forskjeller, kan vi likevel snakke om visse hovedformer for humor:

1. Språkvitser, hvor ett og samme ord kan ha flere betydninger, eller en setning kan tolkes, eventuelt misforstås på flere måter. Det elsker engelskmennene.

2. Misforhold mellom situasjon og beskrivelse. Der kan det morsomme enten ligge i en overdrivelse av virkeligheten - på norsk skrøne - eller det kan ligge i såkalt «understatement», hvor situasjonen beskrives i altfor milde ordelag. Humoren på Vestlandet er ofte preget av sistnevnte, noe en også finner i andre «Nordsjøland», slike som Storbritannia og Island.

3. Tabuvitser, hvor man kommer inn på ting som det egentlig ikke skal snakkes om, for eksempel sex.

4. Morsomheter på andres bekostning. Enkelte betegner det som den sanne humor: Skadefryd er den eneste sanne glede, osv. Denne formen for humor er gjerne ondskapsfull, men den behøver ikke nødvendigvis være det. Det kan også være uttrykk for en dypere forståelse av andres situasjon, noe som vi skal komme tilbake til. Sjølironi hører også til her, like mye som parodier.

5. Crazyhumor er en form som bare går ut på tull, mer og mindre meningsfylt. I samme gruppe har vi det som kalles barokk humor, hvor det groteske har et sterkt innslag.

6. Situasjonskomikk. Her ligger det morsomme i overraskelsesmomentet. Man forventer noe, og så kommer det noe helt annet. Det er ofte dette som får folk til å le når poenget i en vits serveres.

7. Avvergereaksjon. Her er latteren en reaksjon på en mer eller mindre utålelig situasjon, muligens som en beskyttelse. Det var kanskje like naturlig å gråte. Denne form for humor sees ofte i vitenskapen.

(...) Med denne bakgrunnen vandrer vi så inn i den kliniske medisin. La oss se på studenten. Han tar til i studiet hvor opplevelsene i forbindelse med anatomi og disseksjon kan være en stor påkjenning. Seinere i studiet kommer andre og like rystende opplevelser. Enkelte går over til å bli vegetarianere for en tid, og noen fristes til å oppgi studiet. De ser menneskenes bakside hos pasientene og det er mangt som gjør et sterkt inntrykk. (...)

Det kom en sterk, langvarig latter mens de stirret meg intenst inn i øynene

Under den kliniske undervisningen er det rikelig anledning for studentene til å gå i vannet (...) Hør bare på følgende eksempler hentet fra eksisterende journaler:

«Pasienten har sparket fotball i 13 år, ellers frisk.»

«Aktuelt: I 1934 ble pasienten forkjølet.»

«Pasienten svarer til sitt utseende!»

«Pasientens søsken er alle døde, men ingen døde av noen alvorlig sykdom.»

Studentene blir lært opp til at intet må glemmes, og at alle opplysninger i den såkalte anamnesen (tidligere sykdommer) er like viktige. Fra en slik journal henter vi følgende:

«Pasienten spiller i et hornorkester. Orkesteret har øvelse hver onsdag.» 
«Pasienten har vokst opp på en holme utenfor Ålesund.» - (Jeg forestiller meg her at pasienten står ensom og vokser mens sjøene vasker over ham.) (...)

Pasienten har sparket fotball i 13 år, ellers frisk

Ettersom medisinerstudenten rykker oppover i alder og ansiennitet, vil han oppdage at man ler ikke på pasientens bekostning. Det er ondsinnet og nedverdigende. Han vil også oppdage at den første bølge av makaber humor ofte er et overgangsfenomen. Derimot vil han se at mange leger i stedet ler med pasienten. Med det menes en fin, stillferdig humor som røper solidaritet med pasienten og innsikt i hans situasjon. (...)

Hvordan er så humoren i den medisinske vitenskap, eller i biomedisinen, som det heter så fint? Først den ufrivillige: det kan ramme noen hver av oss. (...) Enkelte behandlingsmetoder fra forrige århundre forekommer oss i dag utstyrtelig komiske. Men jeg vet ikke om legene synes det er like morsomt å tenke seg hva neste generasjon kommer til å si om dagens behandlingsmetoder. Vi anvender jo i dag i fullt alvor - og med hell - både rottegift og dynamitt på hjertepasienter, det vil si warfarin og nitroglycerin.

Derimot vil han se at mange leger i stedet ler med pasienten

Så har vi ting som blir skrevet seriøst for tøys, slik vi for eksempel finner det i Journal of Irreproducible Results. Men det ligger alltid en snert av alvor under, og enkelte emner i forskningen som kan virke latterlige og usannsynlige i dag, er kanskje en realitet i morgen. $(\ldots)$

[Humoren] er en fin balansegang mellom det reint komiske og det underliggende alvor. På samme måten er det i den kliniske medisin hvor kontakten med pasienten går på flere plan: Det umiddelbart morsomme, og den bakenforliggende dypere forståelse av hans situasjon. Og da er vi tilbake til utgangspunktet: Det med humor er ikke bare spøk. Det er også alvor.

Publisert: 9. desember 2019. Tidsskr Nor Legeforen. DOI: 10.4045/tidsskr.19.0388

(C) Tidsskrift for Den norske legeforening 2020. Lastet ned fra tidsskriftet.no 